\title{
Genome-wide in silico identification and expression analysis of beta-galactosidase family members in sweetpotato [Ipomoea batatas (L.) Lam]
}

Fuyun $\mathrm{Hou}^{1,2+}$, Taifeng $\mathrm{Du}^{1+}$, Zhen Qin ${ }^{2}$, Tao Xu' ${ }^{1}$, Aixian $\mathrm{Li}^{2}$, Shunxu Dong ${ }^{2}$, Daifu Ma ${ }^{1}$, Zongyun $\mathrm{Li}^{i^{*}}$ (D), Qingmei Wang ${ }^{2}$ and Liming Zhang ${ }^{1,2^{*}}$

\begin{abstract}
Background: Sweetpotato (Ipomoea batatas (L.) Lam.) serves as an important food source for human beings. $\beta$ galactosidase (bgal) is a glycosyl hydrolase involved in cell wall modification, which plays essential roles in plant development and environmental stress adaptation. However, the function of bgal genes in sweetpotato remains unclear.

Results: In this study, 17 ß-galactosidase genes (Ibbgal) were identified in sweetpotato, which were classified into seven subfamilies using interspecific phylogenetic and comparative analysis. The promoter regions of Ibbgals harbored several stress, hormone and light responsive cis-acting elements. Quantitative real-time PCR results displayed that lbbgal genes had the distinct expression patterns across different tissues and varieties. Moreover, the expression profiles under various hormonal treatments, abiotic and biotic stresses were highly divergent in leaves and root.

Conclusions: Taken together, these findings suggested that lbbgals might play an important role in plant development and stress responses, which provided evidences for further study of bgal function and sweetpotato breeding.
\end{abstract}

Keywords: Sweetpotato, $\beta$-galactosidase, Gene expression, Stress

\section{Background}

$\beta$-galactosidases (EC 3.2.1.23; bgal) widely exist in higher plants. Plant $\beta$-galactosidase belongs to the glycoside hydrolase 35 (GH35) families [1], which catalyzes the removal of terminal galactosyl residues from carbohydrates, glycoproteins and galactolipids [2, 3]. In plants, $\beta$-galactosidase has been reported to degrade structural

\footnotetext{
* Correspondence: zongyunli@jsnu.edu.cn; zhanglm11@sina.com

${ }^{\dagger}$ Fuyun Hou and Taifeng Du contributed equally to this work.

'Key laboratory of phylogeny and comparative genomics of the Jiangsu

province, School of Life Sciences, Jiangsu Normal University, Xuzhou 221116, China

Full list of author information is available at the end of the article
}

polysaccharides in plant cell walls to release free galactose during a variety of biological processes, including cell wall expansion and degradation, metabolic recycling of galactolipids and glycoproteins, and turnover of signaling molecules during ripening $[4,5]$.

In higher plants, bgals have been grouped into two classes based on their substrate preference [6]. Enzymes in the first class prefer pectic $\beta-(1 \rightarrow 4)$-galactan as the substrate, and enzymes in the other prefer the $\beta-(1 \rightarrow 3)$ and $(1 \rightarrow 6)$-galactan backbones of arabinogalactan proteins $[7,8]$. A typical bgal protein contains the GH35 conserved site in the N-terminal region [9]. Like other

(c) The Author(s). 2021 Open Access This article is licensed under a Creative Commons Attribution 4.0 International License, which permits use, sharing, adaptation, distribution and reproduction in any medium or format, as long as you give appropriate credit to the original author(s) and the source, provide a link to the Creative Commons licence, and indicate if changes were made. The images or other third party material in this article are included in the article's Creative Commons licence, unless indicated otherwise in a credit line to the material. If material is not included in the article's Creative Commons licence and your intended use is not permitted by statutory regulation or exceeds the permitted use, you will need to obtain permission directly from the copyright holder. To view a copy of this licence, visit http://creativecommons.org/licenses/by/4.0/ The Creative Commons Public Domain Dedication waiver (http://creativecommons.org/publicdomain/zero/1.0/) applies to the data made available in this article, unless otherwise stated in a credit line to the data. 
glycosidase families, bgal genes are ubiquitously expressed in many plants, such as tomato [2], papaya [10], Arabidopsis [11], Brassica campestris [12] and rice [13].

Plant bgal genes are widely involved in the modification of the architecture of cell walls and intercellular attachments [14, 15]. bgal genes also respond to plant growth and development including fruit development and ripening [16, 17], seed germination [18, 19], and root development $[20,21]$. In most fruits, bgal genes exhibit differential expression patterns during flowering and fruit development [12, 16]. In Cicer arietinum, Canbgal-5 expression is relevant to young and meristematic stages with a high cell division rate, while CanBGal-1 and CanBGal-4 are strongly related to later stages of epicotyl growth [3]. In addition, bgal genes can be regulated by abiotic and biotic stresses [22]. For example, Atbgal1 was reported to be induced by salt stress or pathogen attack [23]. Likewise, the transcription level of $\beta$-galactosidase in cowpea is reduced under salt treatments [24], and the bgal mRNA level in peach is highly suppressed by water stress [25]. In addition, bgal genes have been found to play a role in a variety of biological processes through ethylene signal transduction $[11,26]$. However, the function of bgal has not been studied in sweetpotato (Ipomoea batatas (L.) Lam).

Sweetpotato is an important food crop which is widely grown in tropical and subtropical areas, especially in Asia and sub-Saharan Africa. Due to its outcrossing hexaploidy $(2 \mathrm{n}=6 \times=90)$, the genomic research in sweetpotato is very complicated $[27,28]$. So far, no highquality genome sequence of sweetpotato has been available. Although bgal genes are widely isolated from many plant species, its function in sweetpotato remains unknown. In the present study, we firstly identified 17 bgal genes (Ibbgal) in sweetpotato, and then investigated their phylogeny, motif compositions and predicted ciselements using various bioinformatics tools. In addition, the expression patterns of these 17 Ibbgal genes in different tissues of two cultivars were investigated under three exogenous hormones, two abiotic and one biotic stress conditions. Our study will lay the foundation for further research on the function of bgal gene in plants, and provide new insight into different regulatory mechanisms in plant growth through bgal-mediated responses to environmental stresses in sweetpotato.

\section{Results}

Identification and characterization of lbbgal genes in sweetpotato

A total of 17 Ibbgal genes were isolated from sweetpotato after local BLAST using the conserved bgal domain. The deduced amino acid sequences of the Ibbgal proteins were used to predict their protein lengths, signal peptides, pI values, molecular weights, sub-cellular localization and the possible $\mathrm{N}$-glycosylation sites (Table 1). Characteristic analysis showed that these 17 Ibbgals were 673 to 1110 aa in length, the predicted MWs and pIs ranged from $74.8 \mathrm{kDa}$ to $125.1 \mathrm{kDa}$ and 5.31 to 6.16 , respectively. The predicted localization of most Ibbgals varied and included the chloroplast, vacuole, and nucleus. Only one Ibbgal, Ibbgal7, was found to be located in the extracellular. Signal peptides analysis revealed that all Ibbgals, except for Ibbgal4, Ibbgal5, Ibbgal10, Ibbgal13 and Ibbgal17, contained a signal peptide. The number of $\mathrm{N}$-glycosylation sites varied from 1 to 6 , wherein Ibbgal13 and Ibbgal16 contained $6 \mathrm{~N}$-glycosylation sites.

\section{Conserved motifs and phylogenetic analysis of the Ibbgal proteins}

In this study, the $\beta$-galactosidase active site was found in all Ibbgal proteins. However, all but Ibbgal13 have the active site consensus sequence GGP [LIVM]xQxE$\mathrm{NE}[\mathrm{FY}]$ of the GH35 $\beta$-galactosidase family. In addition, all Ibbgal members carried a Gal-lectin domain at the Cterminus of the protein sequence, except for Ibbgal2, Ibbgal5, Ibbgal12, Ibbgal13, and Ibbgal17. Motif analysis showed that motif 1 was found in all Ibbgals except Ibbgal13, and motifs 2-6 were found in all Ibbgals except Ibbgal11 and Ibbgal17 (Fig. 1). A total of 34 bgal genes from sweetpotato and Arabidopsis were classified into seven subgroups, designated as A, B, C, D, E, F and G using phylogenetic analysis (Fig. 2). Among these groups, groups A and D were the largest groups with four Ibbgal genes in each. Groups B and E had three Ibbgal genes. However, Ibbgal9, Ibbgal17 and Ibbgal13 were classified into group $\mathrm{C}, \mathrm{F}$ and $\mathrm{E}$, respectively.

\section{Cis-element prediction of lbbgal genes}

To understand the potential transcriptional regulatory mechanisms of the Ibbgal genes, the cis-elements of each Ibbgal promoter sequences were predicted and analyzed (Table 2). The promoters of Ibbgals were classified into at least four types of cis-elements, including plant hormone responsive elements, light responsive elements, stress responsive elements, and other elements. Most Ibbgal promoters had the GARE (gibberellin-responsive element), ERE (ethylene-responsive element) ciselements, AuxRE and CATATGGMSAUR motifs which were involved in plant hormone response. Most Ibbgal promoters, except Ibbgal6, Ibbgal16 and Ibbgal17, contained circadian and EE elements participated in circadian regulation. In addition, at least five light response elements were found in each Ibbgal gene, which might be essential for plant growth and development. Interestingly, the Ibbgals contained the MYC-like and ABRE 
Table 1 Gene and protein analysis of bgals in sweetpotato

\begin{tabular}{|c|c|c|c|c|c|c|c|}
\hline Gene name & $\mathrm{CDS}^{\mathrm{a}}$ & Length $(a a)^{b}$ & $\mathrm{MW}(\mathrm{kDa})^{\mathrm{c}}$ & $\mathrm{pl}^{\mathrm{d}}$ & Subcellular localization & Signal peptides ${ }^{e}$ & $\mathrm{~N}$-glycosylation site ${ }^{f}$ \\
\hline Ibbgal1 & 2529 & 842 & 94.005 & 5.98 & chloroplast & + & 3 \\
\hline lbbgal2 & 2196 & 731 & 81.393 & 8.39 & chloroplast & + & 2 \\
\hline lbbgal3 & 2526 & 841 & 93.635 & 7.27 & vacuole & + & 1 \\
\hline Ibbgal4 & 2529 & 842 & 93.578 & 8.71 & vacuole & - & 1 \\
\hline Ibbgal5 & 2022 & 673 & 74.792 & 6.32 & nucleus & - & 1 \\
\hline Ibbgal6 & 2526 & 841 & 93.665 & 7.94 & chloroplast & + & 1 \\
\hline Ibbgal7 & 2481 & 826 & 7.22 & 9.32 & extracellular & + & 4 \\
\hline Ibbgal8 & 2541 & 846 & 91.829 & 6.37 & vacuole & + & 2 \\
\hline Ibbgal9 & 2463 & 820 & 92.0858 & 5.31 & vacuole & + & 2 \\
\hline Ibbgal10 & 2391 & 796 & 89.004 & 6.83 & nucleus & - & 4 \\
\hline lbbgal11 & 2505 & 834 & 94.335 & 8.57 & chloroplast & + & 5 \\
\hline Ibbgal12 & 2187 & 728 & 80.867 & 9.13 & vacuole & + & 2 \\
\hline Ibbgal13 & 3333 & 1110 & 125.149 & 5.5 & chloroplast & - & 6 \\
\hline Ibbgal14 & 2487 & 828 & 93.578 & 8.71 & vacuole & + & 5 \\
\hline lbbgal15 & 2475 & 824 & 93.72 & 8.58 & chloroplast & + & 5 \\
\hline lbbgal16 & 2412 & 803 & 89.731 & 6.34 & chloroplast & + & 6 \\
\hline Ibbgal17 & 2145 & 714 & 79.382 & 7.99 & chloroplast & - & 2 \\
\hline
\end{tabular}

${ }^{\text {a }}$ The length of Ibbgals coding sequence

${ }^{\mathrm{b}}$ The length of lbbgals protein

cMolecular weight

${ }^{\mathrm{d}}$ Theoretical isoelectric point

e“+" means contain signal peptide, "-" means lack signal peptide

${ }^{f}$ Predicted using NetNGlyc1.0

(Abscisic acid response element) cis-elements mediating the response to abotic stresses.

\section{Expression profiles of lbbgal genes in tissues and different root development stages}

To identify the potential functions of Ibbgal genes, we analyzed the transcript levels of Ibbgals in various tissues of $c v$. Jishu25 and Jishu29, including leaf, stem lip, stem, fibrous root, and storage root. $47 \%$ of Ibbgals had similar expression patterns in five tissues of two cultivars (Fig. 3a). For example, Ibbgal4, Ibbgal10, Ibbgal13 and Ibbgal17 were highly expressed in five tissues, whereas Ibbgal14, Ibbgal15 and Ibbgal16 were poorly expressed in these tissues. Intriguingly, the expression of Ibbgal4 in fibrous root was significantly higher than that of storage root, while Ibbgal3 and Ibbgal10 were expressed at higher levels in lip than other tissues. However, the transcript of Ibbgal17 mRNA in $c v$. Jishu 25 was prominently higher in storage root than fibrous root, whereas that in cv. Jishu29 had no significant difference in the roots. Similarly, the expression of Ibbgal11 had the opposite pattern in the storage and fibrous roots between $c v$. Jishu25 and Jishu29. In root development stages, 6 (35.3\%) Ibbgal transcripts were down-regulated including Ibbgal2, Ibbgal3, Ibbgal4, Ibbgal6, Ibbgal10, and Ibbgal16, whereas 6 Ibbgal transcripts were up-regulated, two Ibbgal genes (Ibbgal14 and Ibbgal15) were not detected in root development. It is interesting that the Ibbgal11 and Ibbgal12 transcripts had the opposite expression pattern between cv. Jishu25 and Jishu29 (Fig. 3B).

\section{Expression profiles of lbbgal genes in response to abiotic and biotic stresses}

Besides their functions in plant growth and development, Ibbgal genes may also be involved in response to biotic and abiotic stressses. For sweetpotato, salinity and drought are the most dominant factors which limit the growth and yield among various abiotic stresses. Under salt stress, all Ibbgal genes were up-regulated in these two cultivars (Fig. 4). Some genes had the highest expression levels at $12 \mathrm{~h}$ in the leaves, whereas other Ibbgal genes in roots were expressed at a high level at $6 \mathrm{~h}$ and $48 \mathrm{~h}$ after salt stress. In addition, Ibbgal2, Ibbgal4, Ibbgal5 and Ibbgal13 in the leaves were up-regulated remarkably by at least 10 -fold induction after salt stress. These results indicated that Ibbgal genes were involved in salt stress response in sweetpotato. Under drought stress (Fig. 4), all Ibbgal genes were up-regulated in the leaves and roots of $c v$. Jishu29, while Ibbgal3, Ibbgal6, Ibbgal10, and Ibbgal17 were down-regulated in the leaves of Jishu25, Ibbgal1, Ibbgal3 and Ibbgal16 expression were also reduced in the root of Jishu25. Amongst 


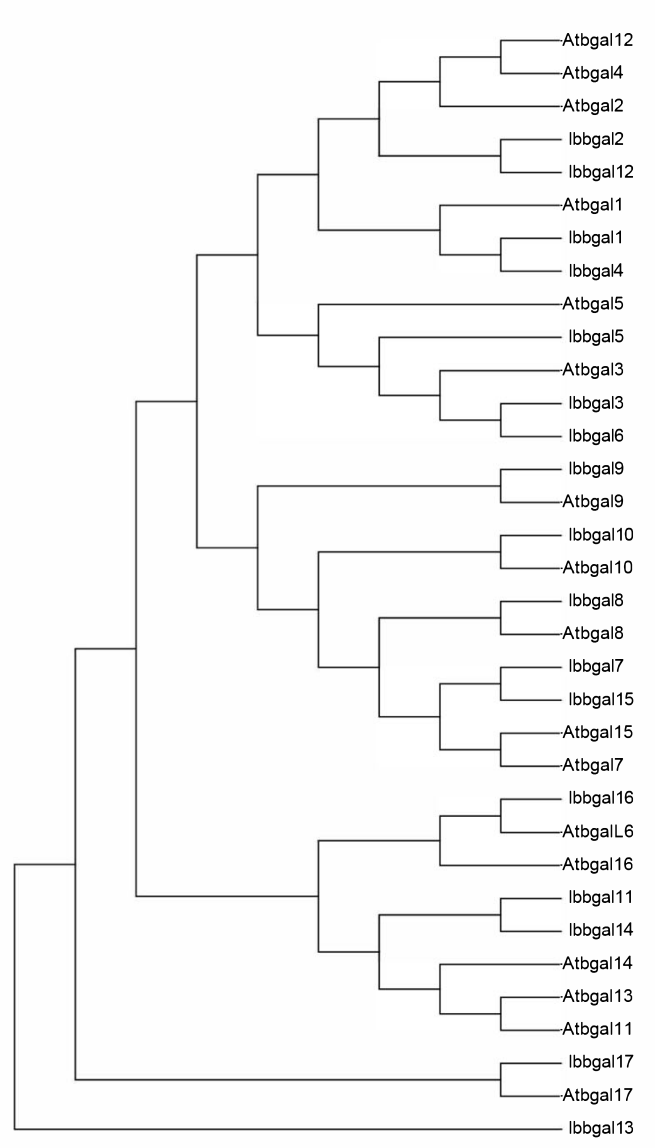

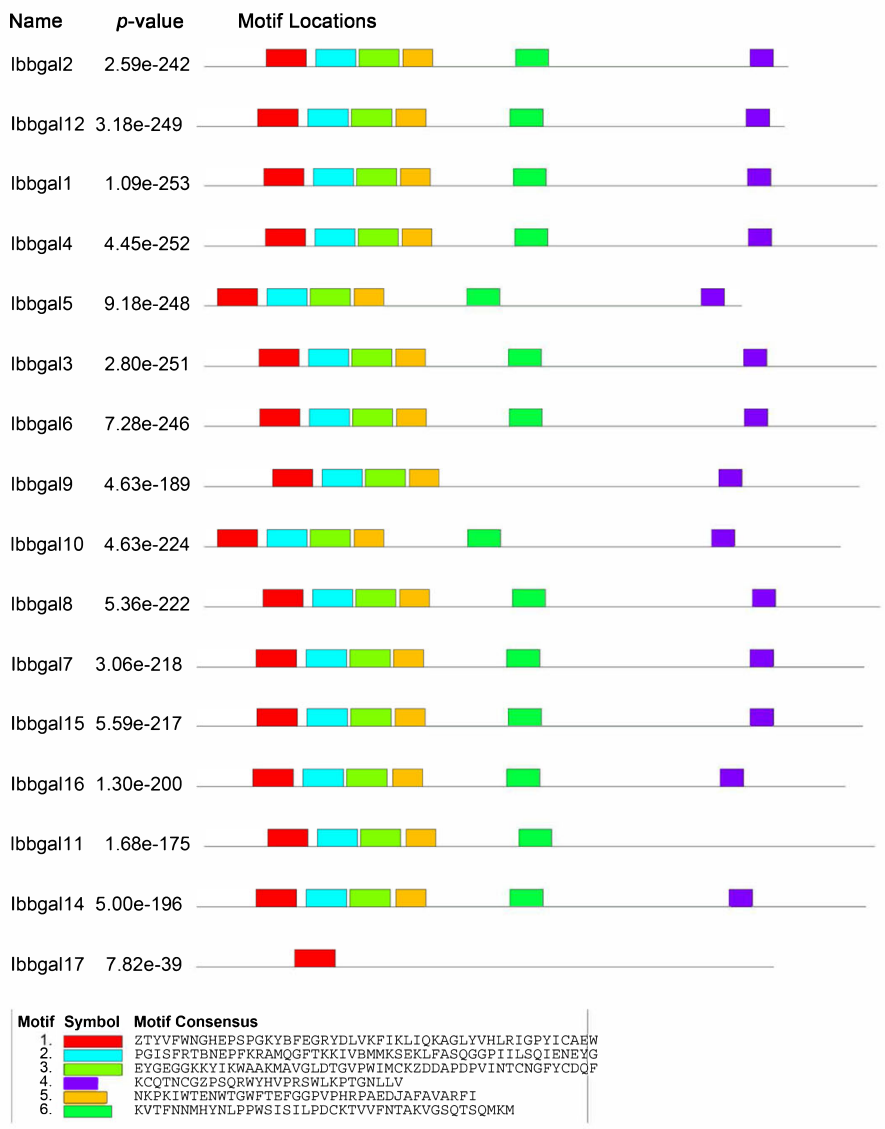

Fig. 1 Phylogenetic relationship of Ibbgal proteins and motifs distribution of Ibbgal genes. a. Phylogenetic relationship among sweetpotato Ibbgals and Atbgals proteins. The uprooted tree was generated using MEGA7.0 by the NJ method. b. Motif distribution in Ibbgal genes. The motifs were obtained from online tool MEME. The upper part represents the composition and position of motifs of Ibbgals with six motifs shown in distinct colors. The lower part shows the motifs of Ibbgals with the symbol of each residue

the up-regulated genes, the expression of Ibbgal2, Ibbgal4, Ibbgal8, Ibbgal9 and Ibbgal13 reached the peak at $12 \mathrm{~h}$ after stress, and Ibbgal4 was the most up-regulated gene with at least 81 -fold induction in the two cultivars leaves, suggesting that Ibbgals in the different cultivars responded to drought treatment differently. Black spot, caused by Ceratocystis fimbriata(C. fimbriata), is one of the main diseases in sweetpotato production, which seriously affects the quality and yield of sweetpotato. After the pathogen infection, Ibbgal genes had different expression patterns in the leaves and roots of these two cultivars (Fig. 4). Ibbgal5, Ibbgal10, Ibbgal11 and Ibbgal16 transcripts were induced by the pathogen infection in these two cultivars. It is worth noting that Ibbgal15 expression in the leaves and roots of $c v$. Jishu25 was up-regulated, whereas downregulated in $c v$. Jishu29. Collectively, these results implied that Ibbgal genes in the different cultivars might have different functions under abiotic and biotic stresses.
Expression profiles of lbbgal genes in response to various hormone treatments

To survey the role of Ibbgal genes in plant hormone response, the expression patterns of Ibbgals were analyzed under three different hormone treatments. After the uniconazole treatment, the expressions of eight Ibbgal genes (including Ibbgal3, Ibbgal6, Ibbgal9-12, Ibbgal16 and Ibbgal17) were induced to the varying degrees in the leaves and roots of these two cultivars (Fig. 5). Interestingly, Ibbgal4 and Ibbgal8 expression were up-regulated in $c v$. Jishu25, whereas down-regulated in $c v$. Jishu29 after the uniconazole treatment, indicating that the same bgal genes of sweetpotato could respond to uniconazole treatment differently in the different genotypes. After the $\mathrm{GA}_{3}$ treatment, the accumulation of four Ibbgals (including Ibbgal4, Ibbgal6, Ibbgal11, and Ibbgal12) were unregulated, while Ibbgal5 was down-regulated in two cultivars (Fig. 5). Among these Ibbgals, Ibbgal4 was the 


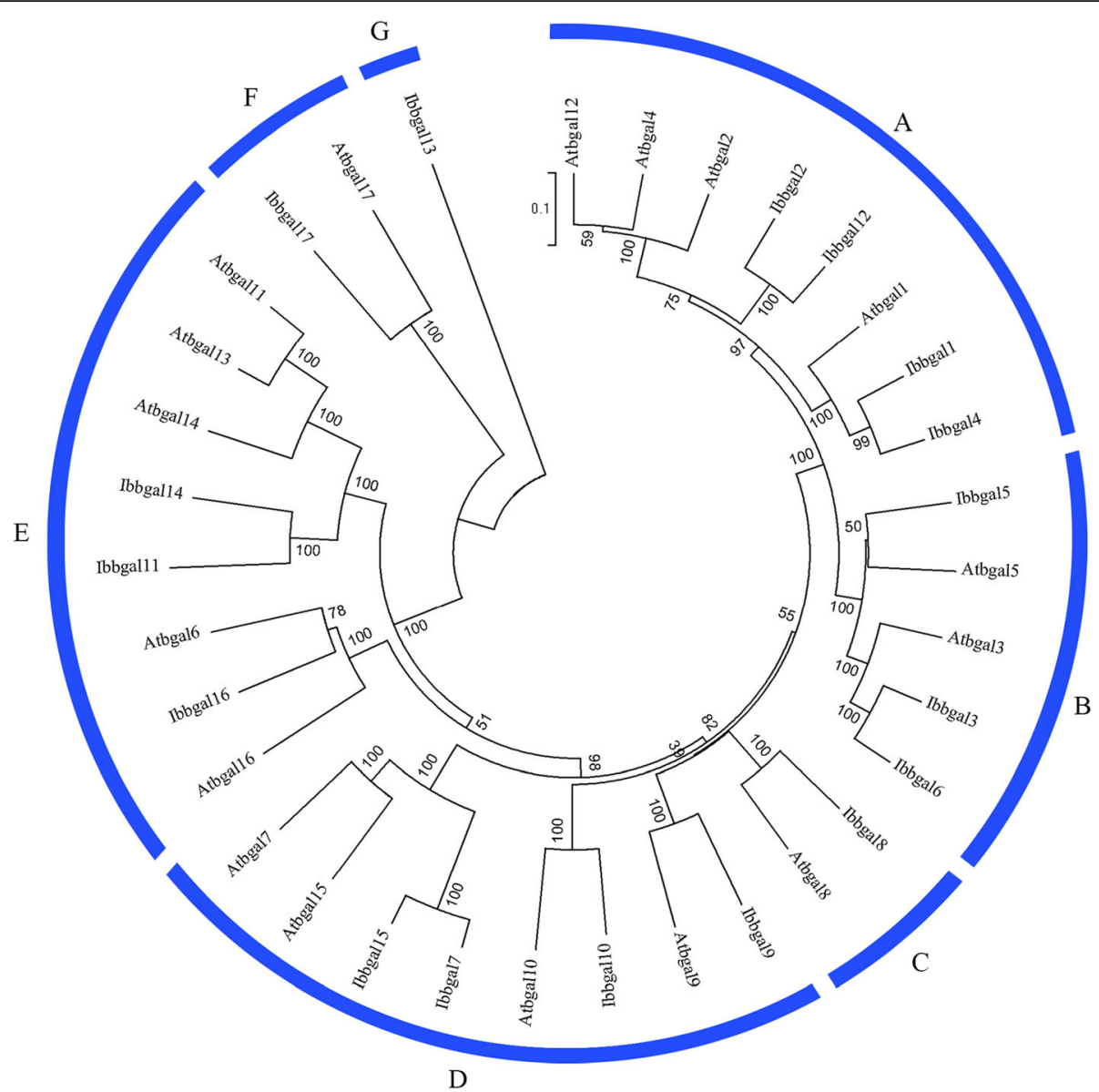

Fig. 2 Phylogenetic tree of bgal proteins in sweetpotato, and Arabidopsis. The bgal protein sequences of Arabidopsis were downloaded from the database of Arabidopsis from the NCBI database. The phylogenetic tree was constructed using MEGA 7.0 by the Maximum-Likelihood method analysis with 1000 bootstrap replications. The tree was classified into 7 different subfamilies indicated by outer rings with blue color

most up-regulated gene, whereas Ibbgal12 was the least up-regulated gene. In addition, $\mathrm{GA}_{3}$ treatment increased the expression of Ibbgal5 and Ibbgal10 in cv. Jishu29, but decreased the expression in $c v$. Jishu25. For the ABA treatment, most Ibbgal transcripts were induced in the leaves of these two cultivars (Fig. 5). In the roots, most Ibbgal transcripts were up-regulated under the stress, except for Ibbgal1 and Ibbgal15. Among the upregulated genes, Ibbgal4 was significantly induced in $c v$. Jishu25, while it was slightly up-regulated in $c v$. Jishu29. These data indicated that sweetpotato bgal genes might play pivotal roles in hormone-response pathways.

\section{Discussion}

$\beta$-galactosidase participates in cell wall biogenesis and modification during plant growth [15, 17]. In this study, 17 $\beta$-galactosidase cDNAs were isolated from sweetpotato, which have the same number of $\beta$-galactosidases as in Arabidopsis, tomato and peach [17, 29]. All Ibbgals except Ibbgal13 had the active site consensus sequences GGP[LIVM]xQxENE[FY]. Most Ibbgal members contained a Gal-lectin domain at the C-terminus, which might be responsible for substrate specificity of bgals [11, 29]. In addition, most Ibbgals were predicted to have signal peptides in the N-terminus, which might be involved in cell wall-related biological processes [29]. The phylogenetic tree was constructed using the bgal proteins from sweetpotato and Arabidopsis, which was similar to those of tomato and rice $[13,29]$. This result implied that the bgals in the same branch might have similar and distinct functions, and bgal diversification might occur in the early stage of plant evolution. Ibbgal4 and Atbgal1 of groups A shared the same clade, suggesting that they might have similar functions.

In a previous study, Esteban et al. (2005) found that bgal genes participate in the development of vegetative organs in Cicer arietinum [3]. Atbgal genes were reported to have differential tissue-specific expression patterns [11]. Similarly, the expression patterns of Ibbgals were distinct in different tissues of sweetpotato in this study. Most Ibbgal genes were expressed in all tissues, whereas Ibbgal14, Ibbgal15 and Ibbgal16 had low expression levels in five tissues. The results are consistent 
Table 2 The putative cis-elements in the promoters of 17 lbbgal genes

\begin{tabular}{|c|c|c|c|c|}
\hline Gene & Plant hormone response elements & $\begin{array}{l}\text { Stress response } \\
\text { elements }\end{array}$ & Light response elements & Other elements \\
\hline lbbgal1 & $\begin{array}{l}\text { ABRE }^{4}, \text { AuXRE } \\
\text { NEBOXHVEPB }\end{array}$ & $\begin{array}{l}\text { box-W } \\
\text { ACGT }^{2}, \text { MYC-like }^{18}\end{array}$ & 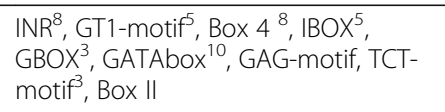 & $\begin{array}{l}\text { EEs, TATA-box }{ }^{21}, \mathrm{GT}^{15}, \text { CCAAT- } \\
\text { box }^{3}, \text { AAGAA-motif }\end{array}$ \\
\hline lbbgal2 & $\begin{array}{l}\text { GARE }^{4}, \text { TGACG-motif2, DPBFCOREDCDC3 }^{2}, \\
\text { CATATGGMSAUR }^{4}\end{array}$ & $\begin{array}{l}\mathrm{MBS}^{2}, \mathrm{MYC}^{-1 i k e} e^{18} \\
\mathrm{ACGT}^{2}\end{array}$ & $\begin{array}{l}\text { INR }^{3}, \text { IBOX }^{2}, \text { GATAbox }^{14}, \text { GAG-motif, } \\
\text { TBOX }^{2}, \text { TCT-motif } \\
\text {,AT1-motif }\end{array}$ & $\begin{array}{l}\text { Circadian }{ }^{2}, \text { TATA-box }^{18} \text {, CCAAT- } \\
\text { box }^{9}, \text { GCN4-motif, RY-element }^{4}, \\
\mathrm{GT}^{12}\end{array}$ \\
\hline lbbgal3 & ABRE,ERE, DPBFCOREDCDC $3^{3}$, & MYC-like ${ }^{16}, \mathrm{ACGT}^{2}$ & $\begin{array}{l}\text { INR }^{2}, \text { GT1-motif, IBOX } \\
\text { box }{ }^{15} \text {, DRE }{ }^{2}, \text { GATA- } \\
\text { Box } \|^{2}\end{array}$ & $\begin{array}{l}\text { Circadian, TATA-box }{ }^{17} \text {, CCAAT- } \\
\text { box }^{6}, \text { RY-element } \\
2, G^{12}\end{array}$ \\
\hline lbbgal4 & $\begin{array}{l}\mathrm{ABRE}^{5}, \mathrm{GARE} \text {, AuXRE}{ }^{2}, \text { PYRIMIDI } \\
\text { NEBOXHVEPB1 }\end{array}$ & $\begin{array}{l}\text { box-W, MYC-like1 } \\
\text { ACGT }^{8}\end{array}$ & $\begin{array}{l}\text { INR }^{8} \text {, GT1-motif5, Box } 4^{8}, \text { IBOX }^{5} \\
\text { GATAbox } \\
\text { Box II }\end{array}$ & $\begin{array}{l}\text { EEs,TATA-box }{ }^{21}, \text {,CCAAT-box }{ }^{3} \\
\text { GT }^{15}, \text { AAGAA-motif }\end{array}$ \\
\hline lbbgal5 & 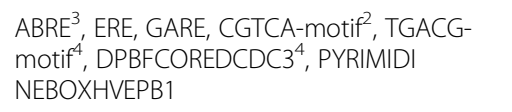 & $\begin{array}{l}\text { LRT, box-W, MYC- } \\
\text { like1 } 1^{2}, \mathrm{ACGT}^{8}, \mathrm{MBS}^{3}, \\
\mathrm{GT}_{1}^{8}\end{array}$ & $\begin{array}{l}\text { INR }^{6} \text {, GT1-motif } \\
\text { GATAbox B Box } 4^{3} \text {, IBOX3, } \\
\text { Box II2 }\end{array}$ & $\begin{array}{l}\text { Circadian }{ }^{3} \text {, TATA-box 15, CCAA } \\
\text { T-box }{ }^{6} \text {, Box A, }\end{array}$ \\
\hline lbbgal6 & $\begin{array}{l}\text { ABRE }^{2}, \text { ERE, GARE }^{2}, \text { CGTCA-motif }^{2} \text {, TGACG- } \\
\text { motif4, DRE2COREZMRAB }{ }^{17} \text {, PYRIMIDI } \\
\text { NEBOXHVEPB1 }\end{array}$ & $\begin{array}{l}\mathrm{LRT}^{3}, \mathrm{MYC}^{\mathrm{M}} \text { like } \\
\mathrm{ACGT}^{10}\end{array}$ & $\begin{array}{l}\text { INR }^{4} \text {, GT1-motif, Box 4, IBOX } 8 \text {, GATA- } \\
\text { box }{ }^{22} \text {, TBOX, TCT-motif }, \text { Box } \|^{4}\end{array}$ & $\begin{array}{l}\text { TATA-box }{ }^{21}, \text { CCAAT-box }{ }^{4}, \text { RY- } \\
\text { element, GT }\end{array}$ \\
\hline lbbgal7 & $\begin{array}{l}\text { ERE, GARE }{ }^{2} \text {, AuxRE, CGTCA-motif, TGACG- } \\
\text { motif }{ }^{3} \text {, DPBFCOREDCDC } 3^{2} \text {, CATATGGM } \\
\text { SAUR }^{2}\end{array}$ & $\begin{array}{l}\text { MYC-like }{ }^{14}, \mathrm{ACGT}^{4} \\
\mathrm{GT}^{5} 1^{5}\end{array}$ & $\mathrm{INR}^{4}, \mathrm{BOX}^{2}{ }^{2}, \mathrm{IBOX}^{14}$, GATAbox $^{17}$ & $\begin{array}{l}\text { Circadian }{ }^{4}, \text { TATA-box }^{17}, \text { CCAAT- } \\
\text { box }^{9}, \text { RY-element }\end{array}$ \\
\hline lbbgal8 & $\begin{array}{l}\text { ABRE }^{3},{\text { ERE, GARE, DPBFCOREDCDC }{ }^{4}, \text { CATA }} \text { TGGMSAUR }^{4}\end{array}$ & $\begin{array}{l}\mathrm{LRT}^{2}, \mathrm{MYC}^{\prime}-\mathrm{like} \mathrm{e}^{20} \\
\mathrm{DRE}^{2}, \mathrm{ACGT}^{12}, \mathrm{MBS}^{2}, \\
\mathrm{GT}^{\prime} 1^{9}\end{array}$ & $\begin{array}{l}\text { INR }{ }^{3}, \text { GT1-motif, Box } 4^{4}, \text { IBOX } \\
\text { box }{ }^{18}, \text { TCT-motif }{ }^{3}, \text { Box } \|^{3}\end{array}$ & $\begin{array}{l}\text { Circadian }{ }^{2} \text {, TATA-box }{ }^{20}, \text { CCAAT- } \\
\text { box }^{3}, \text { RY-element }\end{array}$ \\
\hline Ibbgal9 & ABRE, ERE, GARE ${ }^{2}$ & $\begin{array}{l}\mathrm{LRT}^{3}, \mathrm{MYC}-\mathrm{like} \mathrm{e}^{8} \\
\mathrm{ACGT}^{6}, \mathrm{GT}-1^{5}\end{array}$ & $\begin{array}{l}\text { INR }{ }^{3}, \text { GT1-motif, Box } 4^{2}, \text { IBOX }{ }^{13}, \text { GATA- } \\
\text { box } x^{22}, \text { Tbox }^{2}, \text { Box } \|^{3}\end{array}$ & $\begin{array}{l}\text { Circadian }{ }^{5}, \text { EEs, TATA-box }{ }^{28} \\
\text { CCAAT-box }^{3}, \text { GCN4-motif, RY- } \\
\text { element }^{4}\end{array}$ \\
\hline Ibbgal10 & $\begin{array}{l}\text { ABRE }^{2}, \text { GARE,DPBFCOREDCDC3, CATATGGM } \\
\text { SAUR }{ }^{2} \text {,PYRIMIDINEBOXHVEPB1 }\end{array}$ & $\begin{array}{l}\text { box-W, MYC-like }{ }^{18} \\
\text { ACGT }^{12}, \text { MBS }^{3}, \mathrm{GT}^{-1} 1^{2}\end{array}$ & $\mathrm{INR}^{2}, \mathrm{BOX} 4^{3}, \mathrm{IBOX}$ & $\begin{array}{l}\text { TATA-box }{ }^{16}, \text { CCAAT-box }{ }^{3}, \text { RY- } \\
\text { element }^{3}, \text { Box } A^{2}\end{array}$ \\
\hline Ibbgal11 & $\begin{array}{l}\text { GARE }^{3}, \text { CATATGGMSAUR }^{2}, \text { PYRIMIDI } \\
\text { NEBOXHVEPB1 }\end{array}$ & $\begin{array}{l}\text { MYC-like }{ }^{8}, \mathrm{ACGT}^{4} \\
\mathrm{MBS}^{2}, \mathrm{GT}^{-} 1^{2}\end{array}$ & $\begin{array}{l}\text { INR }{ }^{5} \text {, GT1-motif, Box } 4^{3} \text {, IBOX }{ }^{7} \text {, GATA- } \\
\text { box }{ }^{18} \text {, GAG-motif, TBOX }{ }^{2}, \text { TCT-motif, } \\
\text { Box } \|\end{array}$ & $\begin{array}{l}\text { Circadian,TATA-box }{ }^{23} \text {, CCAAT- } \\
\text { box }^{4}, \text { AAGAA-motif, RY-element }\end{array}$ \\
\hline Ibbgal12 & $\begin{array}{l}\text { ABRE }^{3} \text {, ERE, GARE }{ }^{4}, \text { TGACG-motif, PYRIMIDI } \text { NEBOXHVEPB1 }\end{array}$ & $\begin{array}{l}\mathrm{LRT}^{3}, \text { box-W, MYC- } \\
\text { like }^{18}, \mathrm{DRE}^{4}, \mathrm{ACGT}^{8} \\
\mathrm{GT}^{8}{ }^{8}\end{array}$ & $\begin{array}{l}\text { INRR }{ }^{8} \text {, GT1-motif, Box } 43 \text {, IBOX3, GATA- } \\
\text { box21, TCT-motif, Box } \|^{2}\end{array}$ & $\begin{array}{l}\text { Circadian }{ }^{2} \text {, TATA-box }{ }^{27}, \text { CCAAT- } \\
\text { box }{ }^{3} \text {,RY-element }\end{array}$ \\
\hline Ibbgal13 & ABRE $^{3}$, ERE, TGACG-motif, DPBFCOREDCDC3 & $\begin{array}{l}\mathrm{LRT}^{2}, \mathrm{MYC}^{-l i k e}{ }^{18} \\
\mathrm{ACGT}^{6}, \mathrm{MBS}^{2}, \mathrm{GT}^{-1}{ }^{4}\end{array}$ & $\begin{array}{l}\text { INR }^{4}, \text { GT1-motif } \\
\text { GAG-motif, IBOX }{ }^{15}, \text { GATAbox }^{15},\end{array}$ & $\begin{array}{l}\text { Circadian, TATA-box }{ }^{12}, \text { CCAAT- } \\
\text { box }{ }^{4}, \text { RY-element }\end{array}$ \\
\hline lbbgal14 & $\begin{array}{l}\text { ABRE }^{3}, \text { ERE, GARE, TGACG-motif, DPBFCOR- } \\
{\text { EDCDC } 3^{2}, \text { CATATGGMSAUR }}^{4}\end{array}$ & $\begin{array}{l}\mathrm{LRT}^{4}, \text { box-W, MYC- } \\
\text { like }{ }^{14}, \mathrm{ACGT}^{6}, \mathrm{MBS} \\
\mathrm{GT}-1^{3}\end{array}$ & $\begin{array}{l}\text { INR }^{3}, \text { GT1-motif }{ }^{2}, \text { Box } 4, \text { IBOX }{ }^{10}, \text { GATA- } \\
\text { box }{ }^{18}, \text { CATT, TBOX }\end{array}$ & $\begin{array}{l}\text { Circadian, TATA-box }{ }^{13}, \text { CCAAT- } \\
\text { box }^{6}, \text { RY-element }^{3}\end{array}$ \\
\hline lbbgal15 & GARE $^{2}$, DPBFCOREDCDC $^{2}$ & $\begin{array}{l}\mathrm{LRT}^{3} \text {, box-W } W^{2}, \mathrm{MYC}- \\
\text { like }^{28}, \mathrm{GT}-1^{2}\end{array}$ & $\begin{array}{l}\text { INR }^{4}, \text { GT1-motif }^{2}, \text { IBOX }^{3}, \text { GATAbox }^{10} \\
\text { TBOX }\end{array}$ & $\begin{array}{l}\text { Circadian, TATA-box }{ }^{2} \text {, CCAAT- } \\
\text { box }{ }^{5}, \text { RY-element }\end{array}$ \\
\hline Ibbgal16 & $\begin{array}{l}\text { ERE, GARE }{ }^{2} \text { DPBFCOREDCDC } 3^{3}, \text { CATATGGM } \\
\text { SAUR }^{2}\end{array}$ & $\begin{array}{l}\mathrm{LRT}^{2}, \text { box-W, MYC- } \\
\text { like }{ }^{8}, \mathrm{DRE}^{3}, \mathrm{GT}-1^{6}\end{array}$ & $\begin{array}{l}\text { INR }^{4} \text {, Box } 4^{5}, \text { IBOX}^{2}, \text { GATAbox } \\
\text { motif, GAG- TBOX, TCT-motif }\end{array}$ & $\begin{array}{l}\text { TATA-box }{ }^{36}, \text { CCAAT-box }{ }^{3}, \text { RY- } \\
\text { element }\end{array}$ \\
\hline lbbgal17 & $\begin{array}{l}\text { ABRE }^{7}, \text { ERE, GARE }^{3}, \text { TGACG-motif }^{4}, \\
\text { DPBFCOREDCDC } 3^{6}, \text { CATATGGMSAUR }^{2}, \\
\text { GCCCORE }\end{array}$ & $\begin{array}{l}\mathrm{LRT}^{2}, \text { box-W } \\
\text { like } e^{30}, \mathrm{MCGC}^{0} \mathrm{ACT}^{6}, \mathrm{MBS}^{2} \\
\mathrm{GT}-1\end{array}$ & $\begin{array}{l}\text { INR }^{2} \text {, GT1-motif, Box 4, IBOX } 9 \text {, GATA- } \\
\text { box }{ }^{24}, \text { TBOX, Box II }\end{array}$ & $\begin{array}{l}\text { TATA-box }{ }^{18}, \text { CCAAT-box } \\
\text { GCN4-motif, }^{4} \\
\text { RY-element }\end{array}$ \\
\hline
\end{tabular}

Superscript numbers represent the repeats (2 or more than 2 ) of each cis-element in the lbbgal promoter, while the others only contain one copy of corresponding cis-element

$A B R E$ and $A C G T$ cis-acting elements involved in the abscisic acid responsiveness, AuxRE cis-acting regulatory element involved in auxin responsiveness, $A A G A A$ motif cis-element involved in secondary xylem development, Box $A$ cis-acting elements of phenylalanine ammonia-lyase, Box II part of a light responsive element, Box-W fungal elicitor responsive element, Box 4 part of a conserved DNA module involved in light responsiveness; CATATGGMSAUR, cis-acting element involved in auxin responsiveness, CCAAT-box MYBHv1 binding site, Circadian cis-acting regulatory element involved in circadian control, DPBFCOREDCDC3 induced by ABA; $\mathrm{DRE}$, cis-acting element involved in drought response, $E E s$ part of evening and circadian response, $E R E$ ethylene-responsive element, GARE gibberellin-responsive element, GATA-motif part of a light responsive element, Gbox cis-acting regulatory element involved in light responsiveness, GATAbox part of a light responsive element, GAG-motif part of a light responsive element, GCCCORE, cis-acting element involved in jasmonate responsiveness, GCN4-motif cis-regulatory element involved in endosperm, GT1-motif light responsive element, GT-1 cis-acting element involved in the salt stress, INR part of a light responsive element, IBOX part of a light responsive element, $L T R$ cis-acting element involved in low-temperature responsiveness, MBS MYB binding site involved in drought-inducibility, MYC-like, cis-acting elements of drought-responsive, PYRIMIDINEBOXHVEPB1 cis- and trans-acting elements involved in gibberellins and abscisic acid responsiveness, $R Y$ - 
element cis-acting regulatory element involved in seedspecific regulation, TATA-box core promoter element around -30 of transcription start, TATC-box cis-acting element involved in gibberellin-responsiveness, TBOX part of a light responsive element, TCT-motif part of a light responsive element, TGACG-motif cis-acting regulatory element involved in the MeJA-responsiveness

with the observations in Arabidopsis reported by Gantulga et al. (2009) [30]. A number of cis-elements related to development, such as GCN4_motif, TATA box and RY-element, were found in the promoter of Ibbgal genes $[31,32]$, suggesting that these genes might be related to the development of sweetpotato. Ibbgal2-4, Ibbgal6, Ibbgal10, Ibbgal12 and Ibbgal17 were highly expressed in the early stage of root development. Previous reports have shown that Atbgal5 is involved in root elongation through modifying the cell wall [21, 33]. Lovas et al. (2003) found that Stubgal83 might participate in root and tuber development by altering the metabolic sugar status of the leaves [34]. Thus, we deduced that Ibbgals might be associated with root development by modifying the cell wall and carbohydrate metabolism. Further study is needed to investigate the function of Ibbgal genes during root development in sweetpotato.

To date, increasing evidences manifest that bgal genes are involved in response to various hormone, biotic and abiotic stresses. PaGAL3 and PaGAL4 trancripts in avocado fruit were found to be inhibited by ethylene and ripening signals [26]. In plant coleoptile tissues, auxininduced increase of elongation rate is closely associated with the $\beta$-galactosidase activity $[3,35]$. Li et al. (2003) reported that the $\beta$-galactosidase genes in calamander were down-regulated through IAA, JA and ethylene after infection by fungus C. acutatum of citrus flower [36]. Our study showed that the upstream region of all $I b b$ gals contained three to seven cis-elements related to phytohormone responses, such as GARE, ERE, AuxRE, CATATGGMSAUR. GARE and PYRIMIDINEBOXHVEPB1, which are involved in plant hormone responses [37, 38]. In this study, the expression of eight Ibbgal genes was significantly up-regulated by the uniconazole treatment. Meanwhile, the majority of the Ibbgal genes were regulated by the $\mathrm{GA}_{3}$ treatment in leaves and stems of these two cultivars. ABA is a requisite factor in response to stress, senescence, and fruit development [39, 40]. We found that most Ibbgal genes were induced under ABA treatment. These results revealed that Ibbgal genes mignt play important roles in phytohormone responses. Spadoni et al. (2014) found that the expression levels of $b \mathrm{gal}$ genes decreased in peach fruit after hot water treatment [25]. Several bgal genes are regulated by abiotic and biotic stresses in A. thaliana and Brassica campestris $[12,23,41]$. In addition, the cis-elements related to stress responses, such as MYC-like, LRT, WBOX, MBS and ACGT-motif, have been found in the promoter region of Ibbgal genes, which might regulate gene expression during biotic and abiotic stresses [42, 43]. Similarly, our result showed that most Ibbgal transcripts were related to salt stress, drought stress, ABA treatment and pathogen infection. For example, the expression of all Ibbgal4 was greatly up-regulated by salt and ABA treatments in the leaves of sweetpotato. Taken together, these Ibbgal genes play essential functions in response to biotic and abiotic stresses and their related signal transduction pathways.

In particular, Ibbgals exhibited different stress and hormone response patterns between leaves and roots, and have distinct expression profiles in the two cultivars. There are different in root pectin content from sweetpotato cultivars. $\beta$-galactosidase functions in the degradation of galactan side chains of pectin leading to cell wall loosening and softening $[44,45]$, suggesting that $\beta$ galactosidase may be involved in the regulation of the pectin content, and different bgal-mediated pathways might be activated in the storage root development. In respond to stresses, the accumulated sugar has been reported to involve in osmotic adjustments to sustain cell structure and photosynthesis in plant $[46,47]$. Pandy et al. (2017) found that loss of sugar was the key regulator for activation of the cell wall hydrolase during senescence [48]. $\beta$ galactosidase under abiotic and biotic stresses might be induce the initial structural modification of cell wall and activated to degrade cell wall polysaccharides for producing sugar. Therefore, Ibbgal genes were mainly up-regulated expressed under abiotic and biotic stresses. Further studies need to be performed to investigate the functions of bgals on the stress-response system in sweetpotato.

\section{Conclusion}

We characterized 17 Ibbgal genes and then analyzed their motif compositions and $\mathrm{N}$-glycosylation site. Based on the phylogenetic analysis, the bgals were divided into seven subgroups. We also investigated their promoter regions and sub-cellular location. In addition, we systematically investigated the expression profiles in different tissues, and different development stages of storage roots, as well as the expression of the bgals under six different environmental treatments. The diversification of the bgal genes provides a solid foundation for further elaborating the bgal-mediated stress-response system in sweetpotato.

\section{Methods}

\section{Identification and isolation of lbbgal genes in sweetpotato}

To identify Ibbgal genes, we performed local BLAST and domain search for genes containing the conserved domain of bgals in two transcriptase databases (SRP068179 and CRA000288). The obtained transcript sequences were translated and analyzed by the PFAM program (http:// 


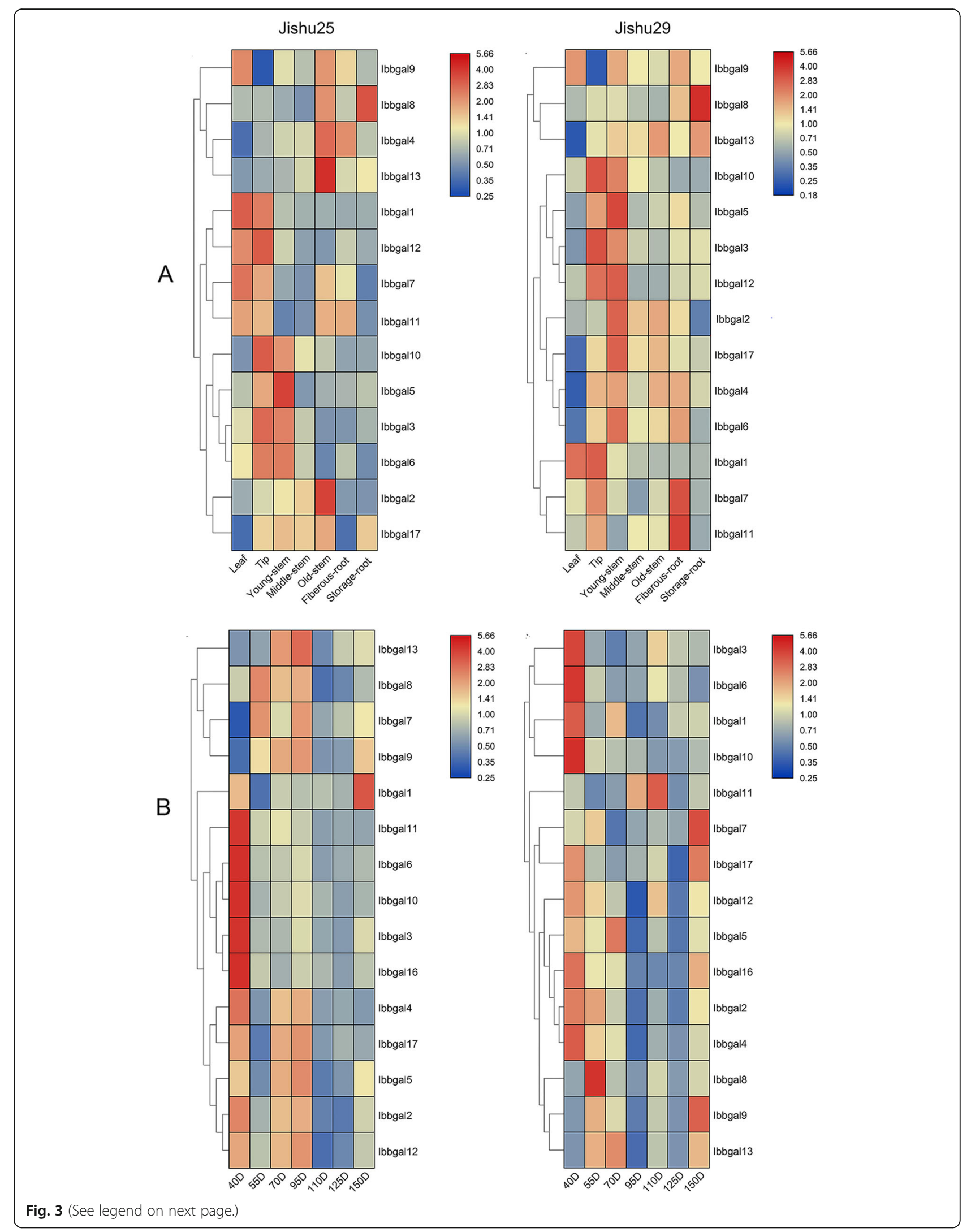


(See figure on previous page.)

Fig. 3 Expression profiles of lbbgal genes in tissues and storage root development of two sweetpotato varieties. a. Expression profiles in the tissues. These tissues include the leaf, tip, young-stem, old-stem, fibrous root and storage root. b. Expression profiles in the storage root development. Gene expression was detected by qRT-PCR. Log-transformed fold-change data were used for creating the heatmaps by TBtools (v1.059). The coloured scale varying from blue to red indicates relatively low or high expressionv

pfam.xfam.org) to examine the presence of the bgal conserved domains. The transcripts encoding proteins which were less than 120 amino acids were removed. The bgal domain was confirmed by analyzing transcripts deduced proteins screened in the NCBI BLAST. If two or more transcripts had the identity of amino acids equal to or higher than $97 \%$, only one of these transcripts was kept in the final list of the genes. Pooled samples including 9 tissues of shoot, leaf, stem, fibrous root, storage toot, flower, salt-treated, drought-treated and ABA-treated plants were collected from two sweetpotato cultivars (Jishu25 and Jishu29). The total RNA was isolated from the pooled sample using TRIzol, and cDNA was synthesized using a reverse transcription Kit (Transgene, China). To isolate the Ibbgal genes, the gene-specific primers were designed used for PCR amplification (Additional file 1). The obtained sequences were compared to the corresponding transcripts, and the related protein data are summarized in Table 1.

\section{Protein properties, $\mathrm{N}$-glycosylation site and subcellular location of the lbbgal proteins}

The molecular weights (MW) and isoelectric points (pI) of Ibbgal genes were analyzed using the ExPasy server

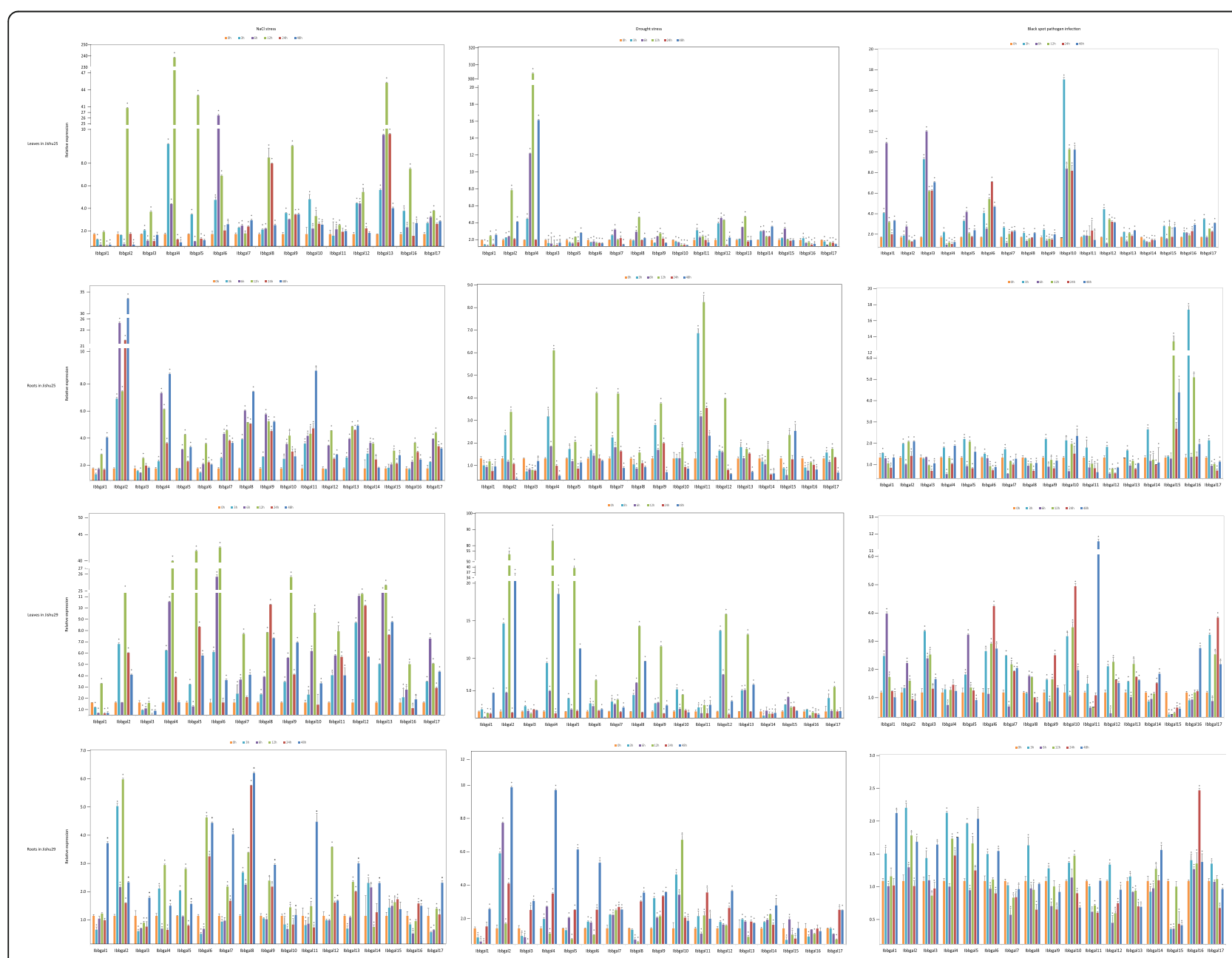

Fig. 4 Expression analysis of lbbgal genes under salt, drought stress and balck spot pathogen infection in the leaves and roots of the two cultivars. Gene expression was detected by qRT-PCR. The $y$-axis represents relative expression, and the data were analyzed using the $2^{-\Delta \Delta C T}$ method. Bars represent the mean of three biological replicates \pm SE. The asteridk indicated that the expression level between the treatment times is significantly different $(P<0.05)$ 


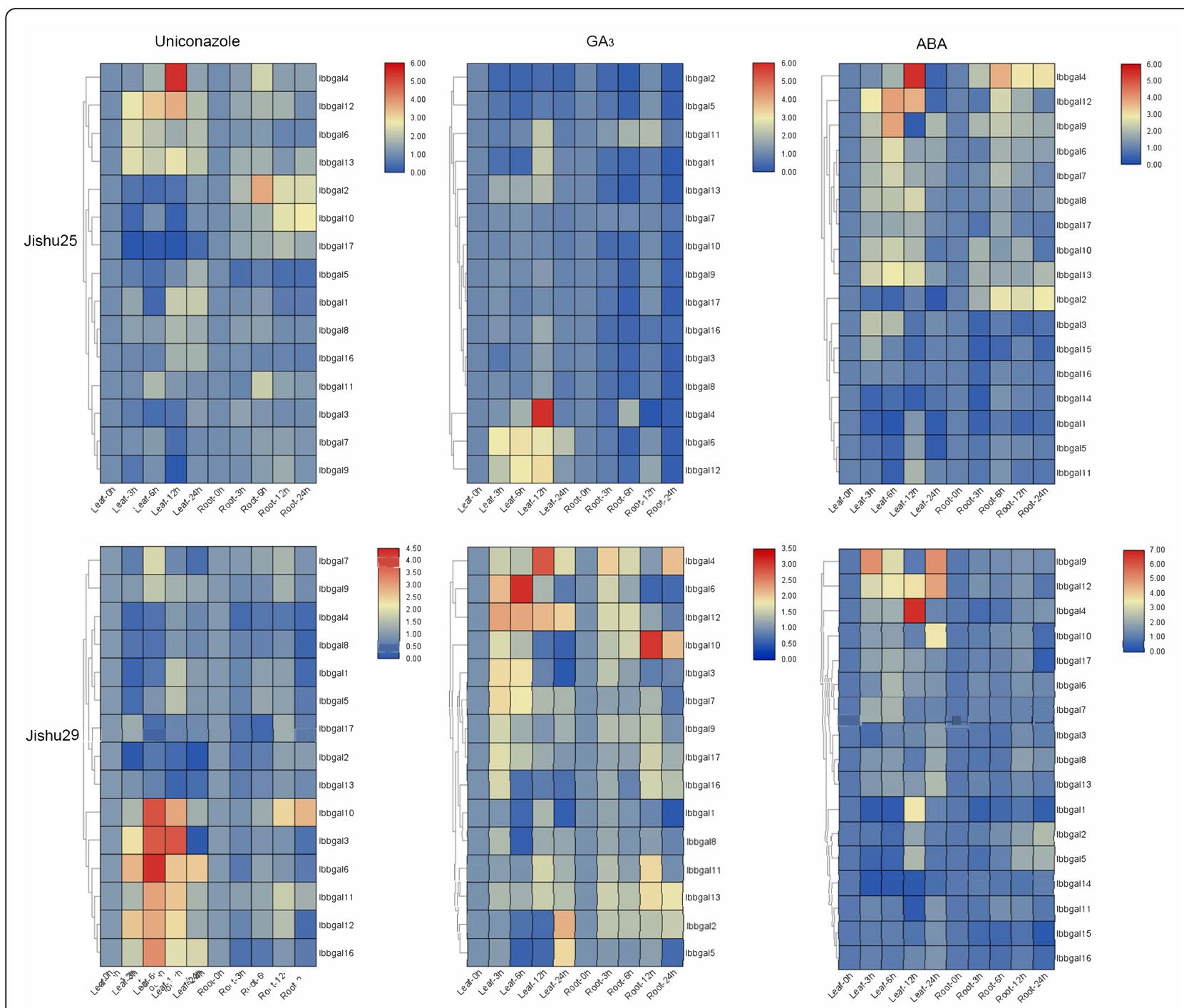

Fig. 5 Expression profiles of Ibbgal genes after uniconazole, $\mathrm{GA}_{3}$ and $A B A$ treatment in the leaves and roots of two cultivars. Gene expression was detected by qRT-PCR. Log-transformed fold-change data were used for creating the heatmaps by Tbtools (v1.059). The coloured scale varies from blue to red, which indicates the low or high expression of each gene

(http://web.expasy.org/protparam/) [49]. N-glycosylation site analysis of Ibbgal genes was conducted using the NetNGlyc 1.0 server (http://www.cbs.dtu.dk/services/ NetNGlyc/) [12]. The WoLF PSORT tools (https:// wolfpsort.hgc.jp/)were used to predict the subcellular location of the Ibbgal proteins [50].

\section{Conserved motifs, phylogenetic analysis and promoter region prediction of the lbbgal proteins}

The conserved domains were identified by the online program SMART (http://smart.embl-heidelberg.de/). These 17 Ibbgal protein sequences were aligned with the MEME server (http://meme-suite.org/tools/meme). The protein sequences of Ibbgals were aligned, and the phylogenetic tree was constructed using the Neighbor-Joining (NJ) method of MEGA software 7.0 [51]. The bgal protein sequences from different species, including Arabidopsis [29], were obtained based on the description in the literature or downloaded from the Plantgdb database (http://www. plantgdb.org/). The promoter sequences (1.5 kb) of Ibbgal genes was obtained from sweetpotato genomic DNA (https://ipomoea-genome.org/\#), and then the cis-acting elements were predicted using the PLACE tool (http:// www.dna.affrc.go.jp/PLACE/) [52].

\section{Quantitative real-time PCR analysis}

To investigate the function of 17 Ibbgals in sweetpotato, the expression patterns were analyzed in various organs, hormone treatments, abiotic and biotic stresses using qRT-PCR. The primer sequences of the examined genes 
were listed in Table S2 (Additional file 2). Total RNA was extracted from the frozen samples by using an RNAprep pure plant kit (TIANGEN, Beijing, China) according to the manufacturer's instructions. qRT-PCR was performed using a Roche LightCycler ${ }^{\circ}$ 480II system under the following conditions: $95^{\circ} \mathrm{C}$ for $15 \mathrm{~s}$, followed by 40 cycles of $95^{\circ} \mathrm{C}$ for $15 \mathrm{~s}, 55^{\circ} \mathrm{C}$ for $15 \mathrm{~s}$ and $72{ }^{\circ} \mathrm{C}$ for $15 \mathrm{~s}$. The $\mathrm{Ib}$-Actin gene was used as an internal reference to evaluate the relative gene expression level. The experiments were conducted for three replicates, and the data were calculated according to the $2^{-\Delta \Delta C T}$ method [53].

\section{Plant materials and stress treatments}

The seedlings of two sweetpotato cultivars ( $c v$. Jishu25 and Jishu29) were collected from the Crop Ressearch Institue, Shandong Academy of Agricultural Sciences, China. The uniform seedlings of the two cultivars were grown in the Hoagland solution at $26^{\circ} \mathrm{C}$ under a photoperiod of $16 \mathrm{~h}$ light $/ 8 \mathrm{~h}$ dark. When the seedlings had five to six functional leaves and adventitious roots of 8 to 10 $\mathrm{cm}$, these seedlings were subjected to six different stresses, respectively. To study the expression patterns under these stresses, the adventitious roots of seedlings were submerged in the solution containing $150 \mathrm{mM} \mathrm{NaCl}, 20 \%$ PEG 6000, $100 \mathrm{mM} \mathrm{ABA}, 50 \mathrm{mg} / \mathrm{L}$ uniconazole, and 50 $\mathrm{mg} / \mathrm{L}$ gibberellic acid $\left(\mathrm{GA}_{3}\right)$ respectively [54]. For black spot pathogen treatment, C. fimbriata conidia was collected after growing in potato dextrose agar (PDA) at $28^{\circ} \mathrm{C}$ for 7 days, then were diluted to $1 \times 10^{4}$ spores $/ \mathrm{mL}$ with sterile water, and then the roots of sweetpotato seedlings were cultivated in the $1 \times 10^{4}$ spores $/ \mathrm{mL}$ conidia suspension. The treated roots and leaves were collected after $0,3,6,12,24$, and $48 \mathrm{~h}$. To investigate the Ibbgals transcript levels in different tissues, the fifth expanded leaves, lips, stems, fibrous roots and storage roots of the two cultivars were sampled at 125 days after transplanting, and the storage roots were sampled at 40, 55, 70, 95, 110, 125 and 150 days after transplanting in the sweetpotato field.

\section{Statistical analysis}

Statistical analysis was performed using the SPSS software package (v13.0), and the datas were presented as means of three replicates. Differences between means were subjected to ANOVA, and the statistical significance of the difference between means was calculated with Duncan's new multiple ranges test and marked with asterisks at $p<0.05$.

\section{Supplementary Information}

The online version contains supplementary material available at https://doi. org/10.1186/s12864-021-07436-1.

Additional file 1: Table S1 The gene-specific primers of lbbgal genes Additional file 2: Table S2 The primer sequences of $17 \mathrm{lbbgal}$ genes for qRT-PCR analysis

\section{Abbreviations}

ABA: Abscisic acid; BLAST: Basic local alignment search tool; bgal: $\beta$ galactosidase; GH35: Glycoside hydrolase 35; GA acetic acid; JA: Jasmonic acid; MW: Molecular weights; NJ: Neighbor joining; pl: Isoelectric points; qRT-PCR: Quantitative reverse transcription polymerase chain reaction

\section{Acknowledgements}

We thank the Ipomoea Genome Hub project team for sharing the Ipomoea batatas genome annotation data (https://ipomoea-genome.org/).

\section{Authors' contributions}

$\mathrm{FH}$ designed and performed the experiments and wrote the paper. TD and ZQ performed some experiments and analyzed the data, AL and SD analyzed the data. TX, DM and QW revised the paper. ZL and LZ conceived the experiment. All authors have read and approved the manuscript.

\section{Funding}

This research was supported jointly by National Key R\&D Program of China (2018YFD1000706, 2018YFD1000700), Postgraduate Research \& Practice Innovation Program of Jiangsu Province (KYCX19_2200), the China Agriculture Research System of sweetpotato (CARS-10-B7), The Priority Academic Program Development of Jiangsu Higher Education Institutions (PAPD),Taishan industry leading talents project (LJNY202002) and Shandong agricultural application technology project (2018-2020). These funding bodies supported this research from inception to completion; ie, the design, data collection, analysis and interpretation of the data, and the writing of the manuscript.

\section{Availability of data and materials}

The datasets analyzed during the current study are available in the GenBank and TAIR repository, the accession numbers of $17 \mathrm{lbbgal}$ genes are MW566714- MW566730, and the bgal protein sequences of Arabidopsis were downloaded from the TAIR database (http://www.arabidopsis.org/).

Ethics approval and consent to participate

Not applicable.

\section{Consent for publication}

Not applicable.

\section{Competing interests}

The authors declare they have no competing interests.

\section{Author details}

${ }^{1}$ Key laboratory of phylogeny and comparative genomics of the Jiangsu province, School of Life Sciences, Jiangsu Normal University, Xuzhou 221116, China. ${ }^{2}$ Crop research institute, Shandong Academy of Agricultural Sciences/ Scientific Observing and Experimental Station of Tuber and Root Crops in Huang-Huai-Hai Region, Ministry of Agriculture and Rural Affairs, Jinan 250100, China.

Received: 28 May 2020 Accepted: 11 February 2021

Published online: 27 February 2021

\section{References}

1. Letunic I, Bork P. Interactive tree of life $\mathbf{V} 2$ : online annotation and display of phylogenetic trees made easy. Nucleic Acids Res. 2011;39:475-8.

2. Smith DL, Gross KC. A family of at least seven $\beta$-galactosidase genes is expressed during tomato fruit development. Plant Physiol. 2000;123:1173-83.

3. Esteban R, Labrador E, Dopico B. A family of $\beta$-galactosidase cDNAs related to development of vegetative tissue in Cicer arietinum. Plant Sci. 2005;168:457-66.

4. Smith DL, Abbott JA, Gross KC. Down-regulation of tomato $\beta$-galactosidase 4 results in decreased fruit softening. Plant Physiol. 2002;129:1755-62.

5. De Alcantara PH, Martim L, Silva CO, Dietrich SM, Buckeridge MS. Purification of a $\beta$-galactosidase from cotyledons of Hymenaea courbaril $\mathrm{L}$. (Leguminosae). Enzyme properties and biological function. Plant Physiol. Biochem. 2006;44:619-27.

6. Kotake T, Dina S, Konishi T, Kaneko S, Igarashi K, Samejima M, Watanabe $Y$, Kimura K, Tsumuraya Y. Molecular cloning of a $\beta$-galactosidase from radish 
that specifically hydrolyzes $\beta-(1 \rightarrow 3)$ and $\beta$ - $(1 \rightarrow 6)$-galactosyl residues of arabinogalactan protein. Plant Physiol. 2005;138:1563-76.

7. Sekimata M, Ogura K, Tsumuraya Y, Hashimoto Y, Yamamoto S. A $\beta$-galactosidase from radish (Raphanus sativus L.) seeds. Plant Physiol. 1989;90:567-74.

8. Hirano Y, Tsumuraya Y, Hashimoto Y. Characterization of spinach leaf a-Larabinofuranosidases and $\beta$-galactosidases and their synergistic action on an endogenous arabinogalactanprotein. Physiol Plant. 1994;92(2):286-96.

9. Henrissat B. Glycosidase families. Biochem Soc Trans. 1998;26:153-6.

10. Lazan H, Ng SY, Goh LY, Ali ZM. Papaya $\beta$-galactosidase/galactanase isoforms in differential cell wall hydrolysis and fruit softening during ripening. Plant Physiol Biochem. 2004;42:847-53.

11. Ahn YO, Zheng M, Bevan DR, Esen A, Shiu SH, Benson J, Peng HP, Miller JT, Cheng CL, Poulton JE, Shih MC. Functional genomic analysis of Arabidopsis thaliana glycoside hydrolase family 35. Phytochemistry. 2007;68:1510-20.

12. Liu J, Gao M, Lv M, Cao J. Structure, evolution, and expression of the $\beta$ galactosidase gene family in Brassica campestris ssp chinensis. Plant Mol Biol Rep. 2013;31:1249-60.

13. Tanthanuch W, Chantarangsee M, Maneesan J, Ketudatcairns J. Genomic and expession analysis of glycosyl hydrolase family 35 genes from rice (Oryza sativa L.). BMC Plant Biol. 2008:8:1-17.

14. McCartney L, Ormerod AP, Gidley MJ, Knox JP. Temporal and spatial regulation of pectic $(1 \rightarrow 4)$ - $\beta$-D-galactan in cell walls of developing pea cotyledons: implications for mechanical properties. Plant J. 2000;22:105-13.

15. Sørensen SO, Pauly M, Bush M, Søkj M, McCann MC, Borkhardt B, Ulvskov P. Pectin engineering: modification of potato pectin by in vivo expression of an endo-1,4-ß-D-galactanase. Proc Natl Acad Sci U S A. 2000;97:7639-44.

16. Othman R, Chong HL, Choo TS, Ali ZM. Three $\beta$-galactosidase CDNA clones related to fruit ripening in papaya (Carica papaya). Acta Physiol Plant. 2011;33:2301-10.

17. Guo S, Song J, Zhang B, Jiang H, Ma R, Yu M. Genome-wide identification and expression analysis of beta-galactosidase family members during fruit softening of peach [Prunus persica (L.) Batsch]. Postharvest Biol Tec. 2018;136:111-23.

18. Buckeridge MS, Reid JS. Purification and properties of a novel $\beta$ galactosidase or exo-(1,4)- $\beta$-D-galactanase from the cotyledons of germinated Lupinus angustifolius L. Seeds Planta. 1994;192:502-11.

19. Chantarangsee M, Tanthanuch W, Fujimura T, Fry SC, Cairns JK. Molecular characterization of $\beta$-galactosidases from germinating rice (Oryza sativa). Plant Sci. 2007:173:118-34.

20. McCartneyy L, Steele-Kingy CG, Jordan E, Knox PJ. Cell wall pectic (1-4)-b-Dgalactan marks the acceleration of cell elongation in the Arabidopsis seedling root meristem. Plant J. 2003;33:447-54.

21. Martín I, Jiménez T, Hernández-Nistal J, Labrador E, Dopico B. The location of the chickpea cell wall bV-galactosidase suggests involvement in the transition between cell proliferation and cell elongation. J Plant Growth Regul. 2009;28:1-11.

22. Sheridan PP, Brenchley JE. Characterization of a salt-tolerant family $42 \beta$ galactosidase from a psychrophilic antarctic planococcus isolate. Appl Environ Microb. 2000;66(6):2438-44.

23. Schmid M, Davison TS, Henz SR, Pape UJ, Demar M, Vingron M, Scholkopf B, Weigel D, Lohmann JU. A gene expression map of Arabidopsis thaliana development. Nat Genet. 2005;37(5):501-6.

24. Sudério FB, Filho EG, Costa JH, Filho JE. $\beta$-Galactosidases from cowpea stems: properties and gene expression under conditions of salt stress. Rev Ciênc Agron. 2014;45(4):794-804.

25. Al S, Guidarelli M, Sanzani SM, Ippolito A, Mari M. Influence of hot water treatment on brown rot of peach and rapid fruit response to heat stress. Postharvest Biol Tec. 2014;94:66-73.

26. Tateishi A, Shiba H, Ogihara J, Isobe K, Nomura K, Watanabe K, Inoue H. Differential expression and ethylene regulation of galactosidase genes and isozymes isolated from avocado (Persea americana Mill.) fruit. Postharvest Biol Tec. 2007:45:56-65.

27. Oziasakins P, Jarret RL. Nuclear-DNA content and ploidy levels in the genus ipomoea. J Am Soc Hortic Sci. 1994;119(1):110-5.

28. Yang J, Moeinzadeh M, Kuhl H, Helmuth J, Xiao P, Liu G, et al. The haplotype-resolved genome sequence of hexaploid Ipomoea batatas reveals its evolutionary history. BioRxiv. 2016. https://doi.org/10.1101/064428.

29. Chandrasekar B, Ra VDH. Beta galactosidases in Arabidopsis and tomatoAmini review. Biochem Soc T. 2016:44:150-8.

30. Gantulga D, Ahn YO, Zhou C, Battogtokh D, Bevan DR, Winkel BSJ, et al. Comparative characterization of the Arabidopsis subfamily a1 $\beta$ galactosidases. Phytochemistry. 2009;70:1999.
31. Grace ML, Chandrasekharan MB, Hall TC, Crowe AJ. Sequence and spacing of TATA box elements are critical for accurate initiation from the betaphaseolin promoter. J Biol Chem. 2004;279:8102-10.

32. Fujiwara T, Beachy RN. Tissue-specific and temporal regulation of a betaconglycinin gene: roles of the RY repeat and other cis-acting elements. Plant Mol Biol. 1994:24:261-72.

33. Albornos L, Martín I, Pérez P, Marcos R, Dopico B, Labrador E. Promoter activities of genes encoding $\beta$-galactosidases from Arabidopsis a1subfamily. Plant Physiol Bioch. 2012;60:223-32.

34. Lovas A, Bimbo A, Szabo L, Banfalvi Z. Antisense repression of Stubgal83 affects root and tuber development in potato. Plant J. 2003;33:139-47.

35. Tanimoto $\mathrm{E}$, Igari M. Correlation between $\beta$-galactosidase and auxin-induced elongation growth in etiolated pea stems. Plant Cell Physiol. 1976;17:673-82.

36. Li W, Yuan R, Burns JK, Timmer LW, Chung KR. Genes for hormone biosynthesis and regulation are highly expressed in citrus flowers infected with the fungus Colletotrichum acutatum, causal agent of postbloom fruit drop. J Amer Soc Hort Sci. 2003;128(4):578-83.

37. Cercos M, Gomez-Cadenas A, Ho THD. Hormonal regulation of a cysteine proteinase gene, EPB-1, in barley aleurone layers: cis- and trans-acting elements involved in the co-ordinated gene expression regulated by gibberellins and abscisic acid. Plant J. 1999;19:107-18.

38. Ogawa M, Hanada A, Yamauchi Y, Kuwahara A, Kamiya Y, Yamaguchi S. Gibberellin biosynthesis and response during Arabidopsis seed germination. Plant Cell. 2003;15:1591-604

39. Wang ZY, Gehring C, Zhu J, Li FM, Zhu JK, Xiong L. The Arabidopsis vacuolar sorting receptor 1 is required for osmotic stress-induced abscisic acid biosynthesis. Plant Physiol. 2015;167:137-52.

40. Wolters H, Jurgens G. Survival of the flexible: hormonal growth control and adaptation in plant development. Nat Rev Genet. 2009;10:305-17.

41. Singh A, Prasad R. Salt stress effects growth and cell wall bound enzymes in Arachis hypogaes L. seedlings. Int J Integr Biol. 2009;7(2):117-23.

42. Simpson SD, Nakashima K, Narusaka Y, Seki M, Shinozaki K, YamaguchiShinozaki K. Two different novel cis-acting elements of erd1, a clpA homologous Arabidopsis gene function in induction by dehydration stress and dark-induced senescence. Plant J. 2003;33:259-70.

43. Abe H, Urao T, Ito T, Seki M, Shinozaki K, Yamaguchi-Shinozaki K. Arabidopsis AtMYC2 (bHLH) and AtMYB2 (MYB) function as transcriptional activators in abscisic acid signaling. Plant Cell. 2003;15:63-78.

44. Dopico B, Nicola SG, Labrador E. Changes during epicotyl growth of an autolysis-related $\beta$-galactosidase from the cell wall of Cicer arietinum. Plant Sci. 1990;72:45-50.

45. Collins PP, O'Donoghue EM, Rebstock R, Tiffin HR, Sutherland PW, Schröder $R$, et al. Cell type-specific gene expression underpins remodeling of cell wall pectin in exocarp and cortex during apple fruit development. J Exp Bot. 2019;70(21):6085-99.

46. Nio SA, Cawthray GR, Wade LJ, Colmer TD. Pattern of solutes accumulated during leaf osmotic adjustment as related to duration of water deficit for wheat at the reproductive stage. Plant Physiol Biochem. 2011;49:1126-37.

47. Fang $Y$, Xiong L. General mechanism of drought response and their application in drought resistance improvement in plants. Cell Mol Life Sci. 2015;72:673-89.

48. Pandey JK, Dash SK, Biswal B. Loss in photosynthesis during senescence is accompanied by an increase in the activity of $\beta$-galactosidase in leaves of Arabidopsis thaliana: modulation of the enzyme activity by water stress. Protoplasma. 2017:254:1651-9.

49. Lu Y, Sun J, Yang Z, Zhao C, Zhu M, Ma D, et al. Genome-wide identification and expression analysis of glycine-rich RNA-binding protein family in sweet potato wild relative Ipomoea trifida. Gene. 2019;686:177-86.

50. Zhang JH, Zhao YH, Xiao HL, Zheng YL, Yue B. Genome-wide identification, evolution, and expression analysis of RNA-binding glycine-rich protein family in maize. J Integr Plant Biol. 2014;56(10):1020-31.

51. Yang Z, Sun J, Chen Y, Zhu P, Zhang L, Wu S, et al. Genome-wide identification, structural and gene expression analysis of the bZIP transcription factor family in sweet potato wild relative Ipomoea trifida. BMC Genet. 2019;20(1):41

52. Lescot M, Déhais $P$, Thijs $G$, Marchal $K$, Moreau $Y$, Rouzé $P$, et al. PlantCARE, a database of plant cis-acting regulatory elements and a portal to tools for in silico analysis of promoter sequences. Nucleic Acids Res. 2002;30(1):325-7.

53. Livak KJ, Schmittgen TD. Analysis of relative gene expression data using realtime quantitative PCR and the $2^{-\Delta \Delta C T}$ method. Methods. 2001;25(4):402-8. 
54. Yang Z, Zhu P, Kang H, Liu L, Cao Q, Sun J, et al. High-throughput deep sequencing reveals the important role that microRNAs play in the salt response in sweet potato (Ipomoea batatas L.). BMC Genomics. 2020;21 (1):164.

\section{Publisher's Note}

Springer Nature remains neutral with regard to jurisdictional claims in published maps and institutional affiliations.

Ready to submit your research? Choose BMC and benefit from:

- fast, convenient online submission

- thorough peer review by experienced researchers in your field

- rapid publication on acceptance

- support for research data, including large and complex data types

- gold Open Access which fosters wider collaboration and increased citations

- maximum visibility for your research: over $100 \mathrm{M}$ website views per year

At BMC, research is always in progress. 